\title{
1 Author and Manuscripts
}

According to Joseph Nasrallah, Yūsuf Šammās, Louis Cheikho, and Georg Graf, Gerasimus was head of the monastery of Saint Simeon the Wonderworker, or Simeon the Stylite, and wrote a book entitled, Kitāb al-Kāfì fì al-Mánā al-Šā $f \bar{\imath}$ (The Complete Book of the Healing Meaning). ${ }^{4}$ Graf dates Gerasimus to the 13 th century, ${ }^{5}$ while Cheikho places him in the 12th or 13th century. ${ }^{6}$ Nasrallah believes that Gerasimus lived at the end of the 13th century. ${ }^{7}$ Based on the list of the scribes at Saint Saba's Monastery in Palestine, which includes the name Gerasimus, René Khawam concludes that this was the same Gerasimus who authored the work we are analysing here, that he studied there at Saint Saba's, and that he was thus a follower of the teachings of John of Damascus. ${ }^{8}$ The scribes who worked on the manuscripts mention that Gerasimus was the superior of the Monastery of Saint Simeon the Stylite, though it is not entirely clear which monastery that would have been. ${ }^{9}$ Khawam believes that this is not Monastery of Saint Simeon in Aleppo, but rather the Saint Simeon Church in Antioch which was established after the Arab invasion by the disciples of Saint Simeon from Aleppo. ${ }^{10}$

Khalil Samir divides the writing of Christian Arabic apologies into four phases, ${ }^{11}$ of which Gerasimus's Apology belongs to the fourth phase (11th-13th centuries), characterized by a spiritual humanistic approach. The Apology presents the Christian faith in a clear logical manner using Greek Aristotelian philosophy. Gerasimus skillfully combines the biblical-homiletical tradition and the logical-philosophical approach.

\subsection{Manuscripts}

I was able to acquire copies of all the known manuscripts of The Apology except Jerusalem, Holy Sepulcher Ar. 101 (17th-18th century). I examined a total of six manuscripts. Four of them contain the complete Apology; only Bierut, Bibliothèque Orientale, Ar. 548, ff. 243-271 and Beirut, Bibliothèque Orientale, Ar. 552, ff. 98-169, are

\footnotetext{
4 Nasrallah 1981, 118; Šammas 2002, 292; Šîhū 1924, 81; Graft 1947, 82-84.

5 Graf 1947, 82-84.

6 Šīhū 1924, 81.

7 Nasrallah 1981, 115.

8 Khawam 1996, 11.

9 For more information about the history of Saint Simeon Monastery see, Nasrallah 1970, 327-356; also Nasrallah 1972, 127-159 - especially 132-153.

10 Cf. Khawam 1996, 15.

11 Samir 1994, 109-114.
}

(c) BY-NC-ND (c) 2014 Abjar Bahkou

This work is licensed under the Creative Commons Attribution-NonCommercial-NoDerivs 3.0 License. 
incomplete, containing only portions of Parts 4 and 5 of the text, respectively. The following is the list of the manuscripts used here:

\begin{tabular}{|c|c|c|}
\hline Manuscripts & Date & Siglum \\
\hline Beirut, Bibliothèque Orientale, Ar. 548, ff. 243-271 & AD 1718 & S1 \\
\hline Beirut, Bibliothèque Orientale, Ar. 552, ff. 98-169 & AD 1718 & S2 \\
\hline Vatican, Biblioteca Apostolica, Sbath 49, ff. 155-252 & AD 1680 & $\mathrm{~F}$ \\
\hline Oxford, Bodleian Library, Marshall Or. 69, ff. 2-113 & AD 1656 & $\mathrm{~B}$ \\
\hline The Maronite Archdiocese of Aleppo, Man. N. 1190 & AD 1700 & $\mathrm{~L}$ \\
\hline The Melkite Archdiocese of Homs, No Number & AD 1701 & $\mathrm{H}$ \\
\hline
\end{tabular}

Gerasimus's writings are divided into two major parts or volumes. The first of these

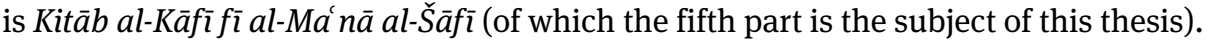
The second includes theological essays on the resurrection of our Lord Jesus Christ and the Christian sacraments: Eucharist, Baptism, and Chrismation (mayrūn).

\subsection{Common Features of Manuscripts}

The six manuscripts I examined are similar in their features, page numbering, and use of margins and vocalizations. In manuscripts F, B, L and H part 4 of the apology has insertions from other portions of the text mixed in. These include portions of Gerasimus's argument regarding baptism, the final paragraphs of the sixth objection from part 5 and arguments from the conclusion of the book. This creates a series of thematic leaps in the text which may cause some confusion in the mind of the reader. S2 is the only manuscript which presents the argument without such leaps. After careful reading, however, in which the various pieces of the argument are put into their respective places, the text becomes much easier to follow.

The margins are treated as essential to the text. First, they are used for the réclame with which the scribes begin the recto side of each folio. ${ }^{12}$ Second, the margin is used

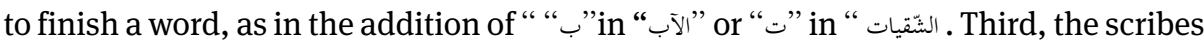
use the margins to fill in what they found missing in the body of the text. The scribe of $\mathrm{L}$ is the only scribe who uses the margins to write his own notes and observations. (See my comments on manuscript L below.) Fourth, the margins contain the folio number.

The scribes vocalize some words that need to be clarified to the reader, introducing especially the šadda and kasra when needed; nouns and verbs اتّخدهُ لنفسهَ، الشّأن، السّلطان are vocalized. The hamza is not utilized with consistency. For example, though they write

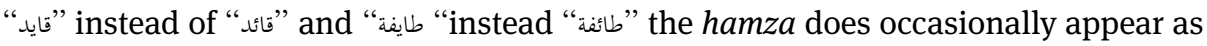
in السماء. The most common treatment of the hamza is substituting "ي" or "ى" for it as in "اسراييل" instead of "ائيل" The distinction between madda and hamza is not clear, as

12 Réclame is the system of citing the last word of the verso as the first word in the following recto. 
the scribes tend to put them together; they write " "أراء" “" Such confusion

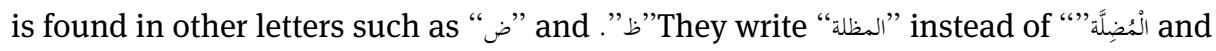
uses " "ي" and" "الي" "instead of " "الى".

\subsection{Beirut, Bibliothèque Orientale, Ar. 548, ff. 243-271 and Ar. 552, ff. 98-169}

Manuscript 548 (S1) (28 folios) contains Part 4 of the Apology, comprised of the testimonies (Šawāhid) and prophecies of the life, death and resurrection of Jesus Christ from the Old Testament, the Qur'an, the books of the Sabians (pagans), and the Greek philosophers. The scribe did not write out the biblical prophecies of the Old Testament because, as he stated in the second manuscript, folio 122-123,

أما كتب العتيقة والحديثة فهي موجودة عندنا. وأمّا شواهد المسلمين والوثنيين ليست عندنا وها نحن نكتبها بعون الله

(Regarding the books of the Old and New [Testaments], we have them already, but the Muslim and Pagan testimonies we do not have. Therefore, we are going to record them with God's help)

This manuscript is carefully written in large letters, in two columns with nine lines in each column. The titles and names are written in red. The name of the copyist is not included.

The second manuscript, 552, ff. 98-169, is written in smaller letters, in two columns with 15 lines each. The scribe used two colors of ink. Titles and important names are written in red ink; the rest of the manuscript is written in black.

At the beginning of the second manuscript, the scribe explains why he did not copy Part 4, which contains Sabian, Jewish and Muslim testimonies, in its entirety. On folio 99 he writes:

$$
\text { وقد ضربنا صفحاً عن كتابة ذلك جميعه لاجل طول شرحه ومعانيه }
$$

(We did not copy them [the testimonies of the Old Testament] because of the length of their commentaries and descriptions of meaning.)

The scribe is very careful in how he describes Muslims and Arabs to the point that he sometimes compromises the purpose of the book by modifying, or changing, offensive words about them. These are the changes he made:

- Folio 243-244, he replaced the Arabic phrase "Kufr al-'arab" (the Arab

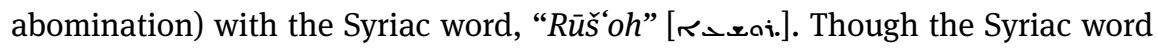
means "evilness" and is equally pejorative, it would not be understood by a Muslim reader unfamiliar with the Syriac language and script.

- Folio 101:

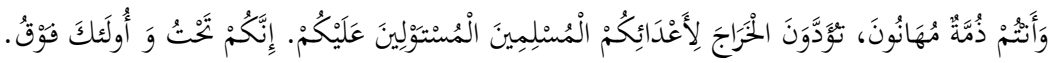

You are humiliated Dhimmi, you pay tribute taxes to your Muslim enemies who are Superior to you. You are below and they are above [in the social hierarchy]. 
He changes the phrase, A'dä'ikum al-Muslimin (your Muslim enemies) to $A^{\prime} d \bar{a}^{\prime}$ ikum (your enemies). Also, he avoided copying the rest of the verse, Ennakom Taht wa Aūla'ka Faūq (you are below and they are above).

- In the same folio he changes the phrase Amma isti'la' 'ummat Muhammad (regarding the ascendance of the nation of Mohammad upon them) to Amma isti 'la' al-'umami (regarding the ascendance of the nations upon them). Also, he changes Sūratu sayf al-Islām (the form of the sword of Islam) to Sūratu sulḍat al-'umam (the form of the Nations ruling over them) (cf. v. 34).

- In Part 5, the response to the first objection, he omitted an entire paragraph (vv. 27-33) which states:

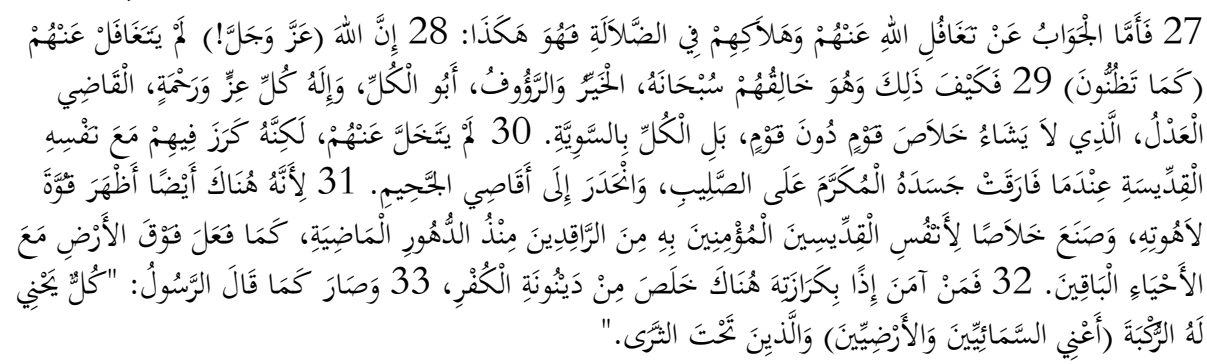

27 In response to [the accusation that] God disregarded [the nations] and let them perish in error, we say: 28 God (the Precious and the Honorable!) did not disregard them, as you assume. 29 How would He do that while He is their Creator (praise be to Him!), the Generous, the Compassionate, the Father of all, the God of all might and mercy, the Just Judge, who desires the salvation not only of some nations to the exclusion of others, but of all nations equally? 30 He did not neglect them, but preached to them, through His Holy Soul, when it was separated from His venerable Body on the Cross, and descended into the farthest depths of Hell. 31 There too, He manifested the power of His Divinity and wrought salvation to the souls of the believing saints who had fallen asleep in previous times, as He did on earth for those who were still alive. 32 Thus, whoever believed in His preaching [there in Hell] was saved from the judgment of unbelief. 33 This fulfills what the apostle said: "Every knee shall bow, the heavenly and earthly, and those under the earth.”

This statement is very offensive to Muslims and their understanding of Christ. According to the Qur'an, Jesus was not crucified. ${ }^{13}$

13 “They killed him not, nor crucified him, but it was made to appear to them." Sūrah 4:157. 


\subsection{Vatican, Biblioteca Apostolica, Sbath. 49, ff. 155-252}

This manuscript contains two works; the first one (ff. 1-154) is entitled Kitāb al-Burhan (The Book of Proof) and was written by Athanasius, the patriarch of Alexandria. The second (ff. 155-252) is Kitāb al-Kāfī fĩ al-Ma'nā al-Šâfī (The Complete Book of the Healing Meaning). The owner of the manuscript, Ğirğs Atanāsīūs, is mentioned on the first page:

$$
\text { اشتراه من ماله لنفسه العبد الحقير جرجس اثناسيوس }
$$

(Bought it, from his own money, the humble servant, Ğirğs Atanāsīūs)

The name, the date of the manuscript and the name of the copyist are mentioned at the bottom of folio 106 in the first work:

1079 للهُجرة الشيخ الْوري يوحنا خادم كنيسة مار الياس الحي للموارنة فِ حلب. سنة 7019 لآدم، 1680 للتجسد،

(The copyist, the elder priest Yūhannā, minister of the Maronite St. Elias Church in Aleppo. In the year 7019 of Adam, 1680 of Incarnation, 1079 of Hijrah.) ${ }^{14}$

This is the only manuscript that changes the word ma'nā, in the title of the book, to its plural form, ma'anni. Also, to the name of the monastery he adds the adjective al-halabi (from Aleppo) to the name of St. Simeon.

The manuscript is written entirely in black ink, no coloring, and the calligraphy is very small. The pages are ruled leaving spaces for margins. There are two columns with 19 lines each. The folio numbers are written in the margins. The copyist also inserted partial punctuation (i.e. periods but not commas or semicolons).

\subsection{Oxford, Bodleian Library, Marshall Or. 69, ff. 2-113}

There is no mention of the copyist nor is a date given in this manuscript. The total number of folios is 113 . The manuscript is carefully written, with the calligraphy very clear and small. The manuscript is written in black ink, no coloring. The pages are ruled leaving space for margins. There are two columns with 19 lines each. The punctuation is limited to periods, with which the scribe ended the sentences. Every folio is designed in two horizontal rectangles, and the titles are also written in designed rectangles.

14 There is a discrepancy between the dating given here and the standard alignment of the Gregorian and Islamic calendars, in which 1680 A.D. would correspond with 1090-1091 of Hijrah. The source of this discrepancy is unclear, as is the source of the belief, implied here, that Adam would have been created in approximately 5339 B.C. 


\subsection{The Melkite Archdiocese of Homs, (1701 AD)}

I acquired a copy of this manuscript from Professor John Lamoreaux, Associate Professor of Religious Studies at Southern Methodist University in Dallas, Texas.

According to Cheikho, this manuscript was first in the collection of Rev. Qustantin al-Bāšā, then in Dr. Sam‘ān's in Homs. It was written by Yūsuf ibn 'Abdallāh, known as "Šidyāq" in the village of Kfar Hildah in al-Btrūn. He was living in Homs at that time. ${ }^{15}$ The total number of folios is 101 ; the calligraphy is very small, in two columns, 21 lines each.

\subsection{The Maronite Archdiocese of Aleppo, Man. N. 1190}

The calligraphy of this document is beautiful and very clear; red ink is used in chapter titles and headings. There are a total of 163 folios and 273 pages with two columns of 15 lines each. For all its beauty though, this manuscript, L, is not very well organized, presenting Gerasimus's arguments in rather disjointed form in places. Some paragraphs from the sixth objection in Part 4 are not copied. The conclusion of the work, which is found at the end of Part 4 in manuscripts B, H, F and S2, is also not copied.

The manuscript is dated according to the Hijrah calendar, as indicated in folio 69:

$$
\text { تم الجزء الثالث بتأييد الله وعونه بيد الفقير الى الله تعالى يوحنا الكاتب سنة } 1005 \text { هجرية }
$$

(The third part is completed in the year 1005 of Hijrah) ${ }^{16}$

Folio 229 includes details of the scribe:

$$
\text { يوحنا الراهب بدير ابراهيم، الدمشقي اصلاً والأرثوذكسي مذهبا }
$$

(Monk Yūhanna, in the monastery of Ibrāhīm, by origin from Damascus, by denomination Orthodox.)

In the left margin of folio 63 the scribe notes that he was able to consult three other copies:

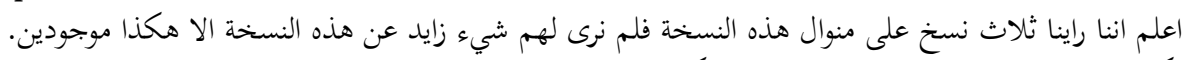

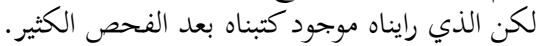

(Know that we have examined three copies that are in accordance with this one. We did not find any extra information that was not in this copy. After a careful examination, we wrote what we read.)

15 Cf. Šìhū 1924, 81.

16 That would be approximately 1600 A.D. 